\title{
6
}

\section{Peer-To-Peer Accommodation in Europe: Trends, Challenges and Opportunities}

\section{Anna Farmaki and Cristina Miguel}

\section{Introduction}

Supported by the principles of the sharing economy (Belk 2014) and enabled by technological advances (Gupta et al. 2019), peer-topeer (P2P) accommodation platforms emerge as new marketplaces to exchange unused accommodation capacity. While there are non-forprofit P2P accommodation platforms such as CouchSurfing (Chen 2018; Miguel 2018) and HomeExchange (Sdrali et al. 2015; Chung 2017), online paid P2P accommodation (Dolnicar 2019), which includes P2P rental platforms and vacation rental platforms, represents the largest

\footnotetext{
A. Farmaki (凶)

Faculty of Management and Economics, Cyprus University of Technology, Limassol, Cyprus

e-mail: anna.farmaki@cut.ac.cy

C. Miguel

Department of Applied IT, Gothenburg University, Gothenburg, Sweden e-mail: cristina.miguel@ait.gu.se
} 
sector of the sharing economy in terms of the transaction value ( $\mathrm{PwC}$ 2016). Companies such as Airbnb, HomeAway and 9Flats have been able to generate a new output of rooms for people to stay in, without the need to create new assets or increase the number of human resources in the company. P2P accommodation occurs when individuals offer a room or an entire property for short-term accommodation. The annual growth rate for global P2P accommodation is estimated at 31\% between 2013 and 2025, six times the growth rate of traditional bed-and-breakfasts and hostels (Bakker and Twining-Ward 2018). The World Economic Forum (2017) predicts that by 2025, the global hotel sector's annual revenue from short-term rentals will increase from 7 to $17 \%$, resulting in the migration of $\$ 8$ billion in annual profits from the hotel industry to the P2P accommodation market sector. Nevertheless, these growth figures have been highly impacted by the effects of the COVID-19 pandemic on tourism and hospitality (AllTheRooms 2020; Hall et al. 2020).

Several attempts were made by researchers to understand the drivers of the P2P accommodation phenomenon. Relevant studies point towards a range of benefits offered to both tourists (guests) and service providers (hosts), which in essence explain the rapid growth of P2P accommodation in Europe (Sthapit and Jimenez-Barreto 2018; Sung et al. 2018). Table 6.1 illustrates the main benefits offered by P2P accommodation to both guests and hosts.

In the case of hospitality exchange platforms, such as CouchSurfing and HomeExchange, the motivation to use these services revolve around saving money (Sdrali et al. 2015; Decrop et al. 2018); building relationships and/or make new friends (Kim et al. 2018; Aydin and Duyan 2019); finding (sexual) partners (Miguel 2018); sharing experiences, intimate information, knowledge and skills (Aydin and Duyan 2019); enjoying helping others (Kim et al. 2018); living 'like a local' (Sdrali et al. 2015; Chung 2017) and sustainability (Forno and Garibaldi 2015).

P2P accommodation platforms offer a number of opportunities, mainly related to the empowerment of individuals in generating revenue using existing assets. This is argued to be a sustainable business model that further democratises tourism by improving the amount and type of accommodation offered and by reducing hotels prices, which is ultimately beneficial for the end-user (Guttentag 2015; Forgacs and 
Table 6.1 Benefits of P2P accommodation to guests and hosts

\begin{tabular}{|c|c|}
\hline & Relevant studies \\
\hline \multicolumn{2}{|l|}{ Guests } \\
\hline Value for money & $\begin{array}{l}\text { Chen and Chang (2018), Tussyadiah } \\
\text { and Pesonen (2018), Tran and } \\
\text { Filimonau (2020) }\end{array}$ \\
\hline Seeking authentic experiences & $\begin{array}{l}\text { Bucher et al. (2018), Paulauskaite et al. } \\
\text { (2017), Shuqair et al. (2019) }\end{array}$ \\
\hline Interaction with locals & $\begin{array}{l}\text { Guttentag et al. (2018), Moon et al. } \\
\text { (2019), Zhu et al. (2019) }\end{array}$ \\
\hline Attributes of the properties & $\begin{array}{l}\text { Belarmino et al. (2019), Tran and } \\
\text { Filimonau (2020) }\end{array}$ \\
\hline $\begin{array}{l}\text { Environmental motives } \\
\text { Hosts }\end{array}$ & Agag (2019), Böcker and Meelen (2017) \\
\hline Income generation & $\begin{array}{l}\text { Fang et al. (2016), Lutz and Newlands } \\
\text { (2018), Sung et al. (2018), Stienmetz } \\
\text { et al. (2020) }\end{array}$ \\
\hline Social interaction & $\begin{array}{l}\text { Karlsson and Dolnicar (2016), Farmaki } \\
\text { and Stergiou (2019) }\end{array}$ \\
\hline
\end{tabular}

Source Own elaboration

Dolnicar 2017; Hajibaba and Dolnicar 2018). On the other hand, P2P accommodation platforms may introduce some challenges resulting from their contribution to the gentrification of cities, regulatory issues and taking over market share from the hospitality industry (Slee 2015; Codagnone and Martens 2016; seen such rapid growth in Europe, with urban areas experiencing a concentration of P2P accommodation units (Gurran and Phibbs 2017), that concerns have been voiced over the associated impacts on local communities and economies. Indeed, there are numerous media reports that draw attention to the problems caused by P2P accommodation growth in relation to the well-being and resilience capacity of Europe's local communities (Williams 2017; Greig 2020). Impacts have also been noticed in the European hotel sector, with Sigala (2017) arguing that P2P accommodation has emerged as one of the greatest disruptors in the hospitality industry.

As a result, there is an ongoing debate over the benefits and costs brought by the P2P accommodation sector in European cities, wherein the phenomenon is more noticeable (Ranchordas et al. 2016). While the emphasis was placed by European intergovernmental organisations on the need to regulate the sector (Hatzopoulos and Roma 2017), this 
has proven to be a difficult task to accomplish considering the varying legal frameworks across European countries (EC 2018). Therefore, this chapter aims to contribute to the continuing debate on the P2P accommodation phenomenon and the implications it carries by examining the key trends influencing the sector's operation and future development while identifying the challenges and opportunities the sector faces in the COVID-19 pandemic era. The rest of the chapter is organised as follows. First, the definition and types of $\mathrm{P} 2 \mathrm{P}$ accommodation are explained. Then, the opportunities generated by P2P accommodation in European cities are analysed in order to explain the reasons for driving the rapid growth of $\mathrm{P} 2 \mathrm{P}$ accommodation in Europe. Moving on, the negative impacts of $\mathrm{P} 2 \mathrm{P}$ accommodation are outlined. Last, the key trends, challenges and opportunities are discussed as conclusions.

\section{P2P Accommodation: Definition and Types}

The growth of the P2P accommodation phenomenon has led to a reordering of resources, skills, and meanings (Richards 2014) within the hospitality sector. P2P accommodation is defined as online networking platforms that allow people to rent out for a short period of time available space within their property and/or the entire property (Belk 2014). In essence, it refers to short-term rental units that are typically offered to prospective guests by their owners who function as hosts and, as such, may additionally offer hospitality services including cooked meals, airport pick-ups and so on. Although accommodation in the form of commercialised homes (e.g., bed \& breakfasts, guesthouses) existed long before the rise of $\mathrm{P} 2 \mathrm{P}$ accommodation, the popularisation of the sharing economy business model in the hospitality sector led to the development of a distinct form of the accommodation offered from peer-to-peer. Sweeney et al. (2018) argued that, at the outset, P2P accommodation might offer services similar to those provided in commercialised homes; yet commercialised homes have been primarily operating on a small scale (Lyu et al. 2019). Contrary, P2P accommodation has arisen due to technology enabling users to share information globally and, in 
turn, encouraging individuals who would not have previously considered renting a room in a private residence to prefer such accommodation options to mainstream ones (Cohen and Kietzmann 2014). The business model of P2P accommodation consists mainly of a service provider (platform), which acts as an intermediary between the supplier (host) and the customer (guest) who will pay for underutilised products and/or services (Kumar et al. 2018). Even though these three parties are a commonality in all P2P accommodation platforms, there are three distinct forms of P2P accommodation.

First, there is P2P accommodation offered for free from hosts to guests via platforms such as Couchsurfing or BeWelcome (Chen 2018; Miguel 2018), where there is no monetary exchange between the parties involved but social and cultural capital exchange (Spitz 2017). As Schuckert et al. (2018) pointed out, these platforms emphasise the social component over the material one. CouchSurfing is often used as an example of the 'pure sharing economy' since there is no monetary exchange between the parties involved (Belk 2014). Geiger and Germelmann (2015), who investigated sharing practices in the context of Couchsurfing, identified that sharing is viewed as a non-profit act, where there is mutual reciprocity between the host and the couchsurfer. At the same time, CouchSurfing can be considered as an 'anti-consumerist' reaction with sharing values (Decrop et al. 2018). According to Kocher et al. (2014), CouchSurfing members are motivated to participate in the service by the sharing of experiences while material sharing (the property) acts as a catalyst. CouchSurfing worked as a charity and was run mainly by volunteers until 2011 when it received \$7 million from venture capitalists and became a corporation (Miguel 2018). Since 2015, CouchSurfing incorporated advertising in the site for users who are not verified, and they also promoted the verification system, which costs $\$ 25$ as another source of revenue (Miguel 2017, 2018). In her study, Miguel (2018) identified that CouchSurfing users found the commercial turn of CouchSurfing controversial as, even though the hospitality exchange service is based on the altruism of its users, some people aim to gain money from couchsurfers' hospitality.

Second, there is reciprocal $\mathrm{P} 2 \mathrm{P}$ accommodation such as that found in platforms such as HomeExchange or LoveHomeSwap where houses are 
swapped between two parties with no monetary exchange taking place between host and guest despite home swappers paying a fee to the platform (Grit and Lynch 2011; Andriotis and Agiomirgianakis 2014). For instance, in the HomeExchange platform, users either pay a membership fee of $€ 120$ per year or pay a $€ 10$ rate per night of stay at someone else's home (HomeExchange 2020). Most platforms offer either reciprocal exchange (which can be simultaneous or non-simultaneous exchange) or exchange with guest points which users collect by previously offering their homes to other users.

Third, there is profit-based P2P accommodation such as that endorsed by the Airbnb, Booking.com or HomeAway platforms whereby a guest pays the host for the service provided. Although Airbnb popularising the P2P accommodation practice (Camilleri and Neuhofer 2017), which consists of either shared property in which the host stays with the guest or the entire property is rented to the guest without the host sharing the same space (Farmaki and Kaniadakis 2020), according to the World Bank Group report (2018) the most successful P2P accommodation platform to date is Booking.com. With almost 5 million listings classified as alternative or non-hotel accommodation, Booking.com emerges as the leader of the P2P accommodation market, followed by Airbnb with 4.85 million listings and HomeAway with 2 million listings (World Bank Group 2018). In different European countries, local paid P2P accommodation platforms have been launched, for instance, Flatio and Mojechaty (Czech Republic), Gloveler and 9flats (Germany), Rentalia, Hundredrooms and Intercambiocasas (Spain), Trumpam (Lithuania), or Realitica and Sobe-Smestaj (Serbia). Some of these platforms operate in different European cities or at a global level (e.g., Hundredrooms, Flatio).

\section{The Case of Airbnb}

Airbnb was first established in 2008 and has quickly expanded in over 191 countries, including more than 200 million members. Around 650,000 Airbnb members are hosts who have approximately 6 million listings worldwide (Airbnb 2020). Such was the rapid growth of the platform that its current estimated value of $\$ 30$ billion exceeds most of the hospitality groups (Cheng and Jin 2019). It is, thus, not surprising that scholars 
suggested that the platform is emerging as a potential threat to the hotel sector (e.g., Guttentag and Smith 2017)

For example, the Airbnb platform opened up its space to commercial hospitality providers such as traditional B\&Bs and boutique hotels through its initiative called 'Airbnb for Everyone'. Accordingly, Airbnb seems to be attracting a group of customers (e.g., business travellers) who would not have previously considered using P2P platforms (Guttentag and Smith 2017). In particular, Airbnb set up a business travel portal with customised search results and introduced a 'business badge' similar to its 'superhost' and 'superguest' badges that are analogous to hotel loyalty schemes and award benefits (e.g., discounts) to dedicated users (Liang et al. 2017)

The platform also introduced 'Airbnb Plus', which refers to an elite selection of properties that have 'exceptional hosts' and 'Airbnb Luxe' that comes with the services of a dedicated concierge in a bid to extend its inventory to more luxurious properties. Airbnb's most recent addition is 'Airbnb Experiences' which refers to tours and activities designed and offered by locals to Airbnb guests with the aim of allowing the visitor to immerse in the local life. Indeed, in recent years, there is a noticeable change in Airbnb's strategies towards more traditional accommodation services, which adds to the debate on whether it may even be regarded as a P2P accommodation platform embracing the sharing economy philosophy (Crommelin et al. 2018)

\section{Opportunities Generated by P2P Accommodation in European Cities}

The impact of the adoption of the sharing economy model on hospitality has also had a wider effect on society. While there are no statistics about the economic impact of home exchange (Andriotis and Agiomirgianakis 2014), it is recognised that users of this type of platform contribute to the economy of several destinations, despite the scale of contribution being marginal compared to paid online P2P accommodation platforms such as Booking or AirBnb (Gössling and Hall 2019). According to a study conducted by Eurostat (2020) about participation in P2P accommodation in the EU, Luxembourg is the country with the most individual hosts $(46 \%)$, followed by Ireland (34\%) and Malta (30\%). Conversely, there were some countries with less than $10 \%$ of the population being 
hosts: Cyprus and the Czech Republic (both 5\%), Latvia (8\%) and Bulgaria (9\%).

Peer-to-peer accommodation involves a number of positive side effects (Forgacs and Dolnicar 2017; Hajibaba and Dolnicar 2018) including: extra income for individuals; micro-entrepreneurship opportunities on services for hosts (cleaning services, key-handling etc.); generation of new jobs since tourism increases as a result of affordable accommodation, increased tax revenues and covering temporarily spiking accommodation needs associated with big events (e.g., Mobile World Congress in Barcelona) or natural disasters. For hosts, P2P accommodation has emerged as a potential arena for micro-entrepreneurship (Stabrowski 2017; Zhang et al. 2019), allowing individuals to gain additional income by using idle assets (Lutz and Newlands 2018; Sung et al. 2018). Generally speaking, it allows hosts to make a living from renting their properties on a short-term basis, thus constitutes their main source of income (Portolan 2012) or additional income (Stienmetz et al. 2020). Correspondingly, through hosting, individuals can improve their standard of living. Nevertheless, some studies (e.g., Heo et al. 2019) show that the profitability for a host is dropping due to the saturation of the market. For example, Heo et al.'s (2019) study about the impact of Airbnb in the hotel industry in Paris found that 'the average occupancy has reached a plateau' and 'profitability for hosts is dropping' (p. 87). In addition to financial gain, social benefits were identified as driving people to participate as hosts in $\mathrm{P} 2 \mathrm{P}$ accommodation when renting rooms in their properties (Farmaki and Stergiou 2019). For example, Farmaki and Stergiou (2019), in their study about Airbnb hosts in Europe, found that several individuals engage in P2P accommodation hosting to combat feelings of loneliness.

In terms of positive effects for consumers, P2P accommodation services, which have been used by $12 \%$ of European citizens (Eurobarometer 2018), provide several competitive advantages against traditional hospitality alternatives. The first one is related to cost. For example, Airbnb hosts are able to provide competitive pricing due to having limited additional labour costs since the platform facilitates the booking and payment process (Guttentag 2015). According to Airbnb (2019), their P2P business model is also democratising tourism since 
'thirty-one percent of the people who travel on Airbnb say they would have stayed home or would not have stayed as long but for Airbnb'. Nevertheless, Guttentag (2016) found in his study that actually from the low-budget users, only $2 \%$ of users would not have travelled if Airbnb did not exist, while $4 \%$ would have stayed with family and friends or CouchSurfing; $17 \%$ would have substituted Airbnb for a hostel, and $10 \%$ for a B\&B. Visitors who choose P2P accommodation benefit from lower prices, and they can spend more money on the tourism sector. As a result, local neighbourhoods have been transformed by spending from increasing numbers of visitors (Fang et al. 2016).

\section{Challenges Generated by P2P Accommodation in European Cities}

Despite the benefits generated by $\mathrm{P} 2 \mathrm{P}$ accommodation, at the same time, the activity produces several negative impacts in the cities where this activity is popular. Local people may encounter some difficulties: increase in their rents; overcrowding by tourists and noise-related issues (Slee 2015; Lee 2016). Slee (2015) highlights that Airbnb is contributing to the massive flow of tourists in cities, preventing them from finding the balance they need between tourism and the other needs of a healthy, sustainable city. In addition, Hajibaba and Dolnicar (2018) point out that the character of neighbourhoods' changes with large numbers of non-residents and inconsiderate short-term visitors can also negatively affect residents' quality of life. Several studies provide evidence that the proliferation of house rentals under this model negatively impact the housing market in European cities (e.g., Sans and Quaglieri 2016; Gutiérrez et al. 2017; Dogru et al. 2019; Cocola-Gant and Gago 2019). Cocola-Gant and Gago (2019) in their study about the impact of Airbnb in Lisbon, Seville, and Barcelona, identified a 'buy-to-let investment process' that increases prices in the centric neighbourhoods and runs away from the sharing economy ethos. Nevertheless, research on this topic is inconsistent, with some studies reporting an increase in pricing when Airbnb listing increase (e.g., Lee 2016) while others do not find any relationship between the two factors (Ranchordas et al. 2016). 
Likewise, scholars expressed concerns over the spatial implications of the phenomenon (Gutiérrez et al. 2017; Ioannides et al. 2019), which enhances the touristification of residential areas. Indeed, as the supply of Airbnb-type rentals intensifies, tourist overcrowding in central areas increases (Ioannides et al. 2019), threatening residents' well-being (Sans and Quaglieri 2016; Stergiou and Farmaki 2020). Additionally, the research highlighted the adverse effects of the growth of P2P accommodation on the hotel sector (Hajibaba and Dolnicar 2017). Nevertheless, evidence from the study conducted by Heo et al. (2019) in the Parisian accommodation market that Airbnb and hotels are not in direct competition. In addition, the (de)regulation of the P2P activity has been discussed by different scholars (e.g., Koolhoven et al. 2016; Ferreri and Sanyal 2018). For instance, Koolhoven et al. (2016) highlight specific liability issues raised by the $\mathrm{P} 2 \mathrm{P}$ accommodation sector in analysing the P2P accommodation regulatory framework in Amsterdam, Barcelona, and Paris since these are the cities with the biggest P2P accommodation activity. Correspondingly, there are increasing pressures placed by industry practitioners and local communities on governments that are called to establish relevant regulatory controls (Farmaki and Kaniadakis 2020).

Nevertheless, Dolnicar and Zare (2020) argue that the problems that some cities experienced with regulating the P2P accommodation market would disappear with the reduced number of P2P accommodation properties. The COVID-19 pandemic has changed the impact of $\mathrm{P} 2 \mathrm{P}$ accommodation since travel restrictions have reduced, to a great extent, the number of travellers during 2020. The P2P accommodation market sector has suffered as a result of a large number of cancellations due to force majeure and falls in reservations during the summer season (Farmaki et al. 2020). In the European market of Airbnb, the cities which have lost the most revenue from the pandemic so far are Barcelona, Berlin, Madrid, Paris, Milan and Rome (AirDNA 2020). As explained by Dolnicar and Zare (2020), COVID-19 has stopped the exponential growth of Airbnb, which has been increasingly incorporating commercial actors and lost its original P2P idea and sharing economy ethos. 


\section{Summary}

This chapter aimed at discussing the evolution of P2P accommodation in Europe in order to identify key trends that shape the sector as well as related operations and practices. In addition, the chapter focused on identifying the various opportunities and challenges brought about by the growth of the P2P accommodation sector in Europe. To start with, the chapter distinguished between different types of $\mathrm{P} 2 \mathrm{P}$ accommodation platforms ranging from paid (e.g., Airbnb, Booking.com) to not-forprofit (e.g., Couchsurfing, BeWelcome) as well as platforms based on home exchanges (e.g., HomeExchange, LoveHomeSwap), explaining the key characteristics and differences among them. The chapter also explored the reasons driving the growth of these platforms, identifying benefits to both hosts and guests as integral for the continuous expansion of the sector in Europe. Although some variation was noticed in the key motives driving P2P accommodation demand and supply depending on the type of platform, total economic and social reasons were found to motivate participation in P2P accommodation exchanges. For instance, individuals rent available space in their properties through $\mathrm{P} 2 \mathrm{P}$ accommodation platforms in order to make a living or supplement their income as well as meet new people from different cultures (Karlsson and Dolnicar 2016; Lutz and Newlands 2018; Stienmetz et al. 2020). Similarly, convenience, value for money and the search for more authentic and localised tourist experience seem to drive demand for P2P accommodation (Bucher et al. 2018; Shuqair et al. 2019; Tran and Filimonau 2020; Zhu et al. 2019).

Evidently, P2P accommodation platforms offer numerous opportunities to both hosts and guests as they represent a tool of empowerment that allows individuals to make more suitable choices regarding their accommodation as well as generate revenue using existing assets and relatively low capital. In turn, P2P accommodation platforms have been argued to contribute to a more sustainable economic development as they advocate business models that democratise the tourism industry (Forgacs and Dolnicar 2017; Hajibaba and Dolnicar 2018) while extending accommodation options and forcing the traditional accommodation sector (e.g., hotels) to respond with more appealing 
offerings. Despite such promising prospects, P2P accommodation has been found to yield several negative impacts on local economies and communities in Europe. The immense growth of the sector in European cities, where the phenomenon is most noticeable, has brought along a range of problems, including overcrowding from the influx of tourists in residential areas, higher pollution levels and increased rent prices, among others (Gurran and Phibbs 2017; Ioannides et al. 2019). In addition to these impacts, the P2P accommodation sector has been argued to inflict great effects on the performance, occupancy levels and revenue of hotels (Sigala 2017), forcing them to respond to the increasing competition and adapt their product by incorporating characteristics of P2P accommodation (e.g., home feeling) in their offering (Zhu et al. 2019).

Within this context, European intergovernmental organisations have been pressurising national governments of European countries to establish a regulatory framework in order to monitor the associated impacts of P2P accommodation growth. The regulation of the sector, nonetheless, is not an easy task as there are varied legal and regulatory systems among European countries. Regulatory attempts are further problematised by the fact that European destinations face varying tourism development levels, forms, and strategies. The COVID-19 pandemic has further highlighted the need for regulation in the sector. The pandemic has had great adverse effects on P2P accommodation leading not only to hosts exiting the platforms but also to guests questioning the level of hygiene and safety standards implemented by individuals in the rented properties. Undoubtedly, the pandemic has exposed the vulnerable aspects of the P2P accommodation sector (Farmaki et al. 2020), calling for greater consolidation of policymaking and regulatory attempts in order to ensure that the interests of users (hosts and guests) and local communities are safeguarded in the foreseeable future. By discussing the key trends pertinent to the growth of the P2P accommodation sector as well as the emerging opportunities and challenges brought about by the phenomenon in Europe, this chapter has contributed to the ongoing debate on the merits and disadvantages of P2P accommodation, which has changed the tourism and hospitality landscape indefinitely. 


\section{References}

Agag, Gooma. 2019. "Understanding the determinants of guests' behaviour to use green P2P accommodation.' International Journal of Contemporary Hospitality Management 39 (9): 3417-3446. https://doi.org/10.1108/ IJCHM-09-2018-0755.

Airbnb. 'Airbnb Fast Facts.' Accessed March 23, 2020. https://press.atairbnb. com/app/uploads/2017/08/4-Million-Listings-Announcement-1.pdf.

AirDNA. 'Impact of Coronavirus on the STR Market.' Accessed May 5, 2020. https://www.airdna.co/blog/coronavirus-impact-on-global-shortterm-rental-markets.

Alltherooms. 2020. Airbnb Statistics. Available at: https://www.alltherooms. com/analytics/airbnb-statistics/.

Andriotis, Konstantinos, and George Agiomirgianakis. 2014. Market escape through exchange: Home swap as a form of noncommercial hospitality. Current Issues in Tourism 17 (7): 576-591.

Aydin, Serhat, and Emin Cihan Duyan. 2019. 'Post-modern tanr1 misafiri: Couchsurfing deneyim süreci.' Journal of Economy Culture and Society 60 (1): 227-243. https://doi.org/10.26650/JECS2019-0003.

Bakker, Martine, and Louise Twining-Ward. 2018. Tourism and the Sharing Economy: Policy and Potential of Sustainable Peer-To-Peer Accommodation. Washington, USA: World Bank.

Belarmino, Amanda, Elizabeth Whalen, Yoon Koh, and John T. Bowen. 2019. 'Comparing Guests' Key Attributes of Peer-To-Peer Accommodations and Hotels: Mixed-Methods Approach.' Current Issues in Tourism 22 (1): 1-7. https://doi.org/10.1080/13683500.2017.1293623.

Belk, Russell. 2014. 'You Are What You Can Access: Sharing and Collaborative Consumption Online.' Journal of Business Research 67 (8): 1595-1600. https://doi.org/10.1016/j.jbusres.2013.10.001.

Böcker, Lars, and Toon Meelen. 2017. 'Sharing for People, Planet or Profit? Analysing Motivations for Intended Sharing Economy Participation.' Environmental Innovation and Societal Transitions 23: 28-39. https://doi.org/10. 1016/j.eist.2016.09.004.

Bucher, Eliane, Christian Fieseler, Matthes Fleck, and Christoph Lutz. 2018. 'Authenticity and the Sharing Economy.' Academy of Management Discoveries 4 (3): 294-313. https://doi.org/10.5465/amd.2016.0161.

Camilleri, Jeannette, and Barbara Neuhofer. 2017. 'Value Co-creation and Co-destruction in the Airbnb Sharing Economy.' International Journal of 
Contemporary Hospitality Management 29 (9): 2322-2340. https://doi.org/ 10.1108/IJCHM-09-2016-0492.

Chen, De-Jung. 2018. 'Couchsurfing: Performing the Travel Style Through Hospitality Exchange.' Tourist Studies 18 (1): 105-122. https://doi.org/10. 1177/1468797617710597

Chen, Chia-Chen, and Ya-Ching Chang. 2018. 'What Drives Purchase Intention on Airbnb? Perspectives of Consumer Reviews, Information Quality, and Media Richness.' Telematics and Informatics 35 (5): 1512-1523. https:// doi.org/10.1016/j.tele.2018.03.019.

Chung, Jin Young. 2017. 'Online Friendships in a Hospitality Exchange Network: A sharing Economy Perspective.' International Journal of Contemporary Hospitality Management 29 (12): 3177-3190. https://doi.org/10. 1108/IJCHM-08-2016-0475.

Cocola-Gant, Agustin, and Ana Gago. 2019. Airbnb, buy to let investment and tourism-driven displacement: A case study in Lisbon. Environment and Planning A: Economy and Space.

Codagnone, Cristiano, and Bertin Martens. 2016. Scoping the sharing economy: Origins, definitions, impact and regulatory issues. Institute for Prospective Technological Studies Digital Economy Working Paper, 1.

Cohen, Boyd, and Jan Kietzmann. 2014. 'Ride on! Mobility Business Models for the Sharing Economy.' Organization \& Environment 27 (3): 279-296. https://doi.org/10.1177/1086026614546199.

Crommelin, Laura, Laurence Troy, Chris Martin, and Chris Pettit. 2018. 'Is Airbnb a Sharing Economy Superstar? Evidence from Five Global Cities.' Urban Policy and Research 36 (4): 429-444. https://doi.org/10.1080/081 11146.2018.1460722.

Decrop, Alain, Giacomo Del Chiappa, Jérôme Mallargé, and Pietro Zidda. 2018. "Couchsurfing has Made Me a Better Person and the World a Better Place': The Transformative Power of Collaborative Tourism Experiences.' Journal of Travel \& Tourism Marketing 35 (1): 57-72. https://doi.org/10. 1080/10548408.2017.1307159.

Dogru, Tarik, Makarand Mody, and Courtney Suess. 2019. Adding evidence to the debate: Quantifying Airbnb's disruptive impact on ten key hotel markets. Tourism Management, 72: 27-38.

Dolnicar, Sara. 2019. 'A Review of Research into Paid Online Peer-ToPeer Accommodation: Launching the Annals of Tourism Research Curated Collection on Peer-To-Peer Accommodation.' Annals of Tourism Research 75: 248-264. https://doi.org/10.1016/j.annals.2019.02.003. 
Dolnicar, Sara, and Samira Zare. 2020. 'COVID19 and Airbnb-Disrupting the Disruptor.' Annals of Tourism Research 83: 102961. https://doi.org/10. 1016/j.annals.2020.102961.

Eurobarometer. 2018. Collaborative economy in Europe. Available at: https:// europa.eu/eurobarometer/surveys/detail/2184.

Eurostat. 'Individuals: use of collaborative economy.' Accessed October 3, 2020. https://ec.europa.eu/eurostat/web/products-eurostat-news/-/DDN20200205-1.

Fang, Bin, Qiang Ye, and Rob Law. 2016. 'Effect of Sharing Economy on Tourism Industry Employment.' Annals of Tourism Research 57: 264-267. https://doi.org/10.1016/j.annals.2015.11.018.

Farmaki, Anna, Cristina Miguel, Maria Hadjielia Drotarova, Ana Aleksić, Anita Čeh Časni, and Fani Efthymiadou. 2020. 'Impacts of Covid-19 on Peer-To-Peer Accommodation Platforms: Host Perceptions and Responses.' International Journal of Hospitality Management 91: 102663. https://doi.org/ 10.1016/j.ijhm.2020.102663.

Farmaki, Anna, and Dimitrios P. Stergiou. 2019. 'Escaping Loneliness Through Airbnb Host-Guest Interactions.' Tourism Management 74: 331-333. https://doi.org/10.1016/j.tourman.2019.04.006.

Farmaki, Anna, and Antonios Kaniadakis. 2020. 'Power Dynamics in Peer-ToPeer Accommodation: Insights from Airbnb Hosts.' International Journal of Hospitality Management 89: 102571. https://doi.org/10.1016/j.ijhm.2020. 102571.

Farmaki, Anna, Dimitrios P. Stergiou, and Prokopis Christou. 2020. 'Sharing Economy: Peer-To-Peer Accommodation as a Foucauldian Heterotopia.' Tourism Review. https://doi.org/10.1108/TR-08-2019-0354.

Ferreri, Mara, and Romola Sanyal. 2018. 'Platform Economies and Urban Planning: Airbnb and Regulated Deregulation in London.' Urban Studies 55 (15): 3353-3368. https://doi.org/10.1177/0042098017751982.

Forno, Francesca, and Roberta Garibaldi. 2015. 'Sharing Economy in Travel and Tourism: The Case of Home-Swapping in Italy.' Journal of Quality Assurance in Hospitality \& Tourism 16 (2): 202-220. https://doi.org/10. 1080/1528008X.2015.1013409.

Garau-Vadell, Joan B., Desiderio Gutiérrez-Taño, and Ricardo Díaz-Armas. 2019. "Residents' Support for P2P Accommodation in Mass Tourism Destinations.' Journal of Travel Research 58 (4): 549-565. https://doi.org/10. $1177 / 0047287518767067$. 
Geiger, Alina, and Claas Germelmann. 2015. Reciprocal Couchsurfing versus sharing's non-reciprocity principle. In Proceeding of the 44th EMAC Conference.

Gössling, Stefan, and C. Michael Hall. 2019. 'Sharing Versus Collaborative Economy: How to Align ICT Developments and the SDGs in Tourism?' Journal of Sustainable Tourism 27 (1): 74-96. https://doi.org/10.1080/096 69582.2018.1560455.

Greig, Jim. 2020. 'European cities Taking Action Against Airbnb.' VICE. Accessed October 30, 2020. https://www.vice.com/en/article/wx8qz5/air bnb-blocked-europe-lisbon-paris-berlin.

Grit, Alexander, and Paul Lynch. 2011. 'An Analysis of the Development of Home Exchange Organisations.' Research in Hospitality Management 1 (1): 19-24. https://doi.org/10.1080/22243534.2011.11828271.

Gupta, Manjul, Pouyan Esmaeilzadeh, Irem Uz, and Vanesa M. Tennant. 2019. 'The Effects of National Cultural Values on Individuals' Intention to Participate in Peer-To-Peer Sharing Economy.' Journal of Business Research 97: 20-29. https://doi.org/10.1016/j.jbusres.2018.12.018.

Gurran, Nicole, and Peter Phibbs. 2017. 'When Tourists Move in: How Should Urban Planners Respond to Airbnb?' Journal of the American Planning Association 83 (1): 80-92. https://doi.org/10.1080/01944363.2016. 1249011.

Guttentag, Daniel. 2015. 'Airbnb: Disruptive Innovation and the Rise of an Informal Tourism Accommodation Sector.' Current Issues in Tourism 18 (12): 1192-1217. https://doi.org/10.1080/13683500.2013.827159.

Guttentag, Daniel. 2016. Why tourists choose Airbnb: A motivation-based segmentation study underpinned by innovation concepts (Doctoral Dissertation, University of Waterloo). https://uwspace.uwaterloo.ca/bitstream/han dle/10012/10684/Guttentag_Daniel.pdf.

Guttentag, Daniel A., and Stephen LJ Smith. 2017. 'Assessing Airbnb as a Disruptive Innovation Relative to Hotels: Substitution and Comparative Performance Expectations.' International Journal of Hospitality Management 64: 1-10. https://doi.org/10.1016/j.ijhm.2017.02.003.

Guttentag, Daniel, Stephen Smith, Luke Potwarka, and Mark Havitz. 2018. 'Why Tourists Choose Airbnb: A Motivation-Based Segmentation Study.' Journal of Travel Research 57 (3): 342-359. https://doi.org/10.1177/004728 7517696980.

Gutiérrez, Javier, Juan Carlos García-Palomares, Gustavo Romanillos, and María Henar Salas-Olmedo. 2017. 'The Eruption of Airbnb in Tourist 
Cities: Comparing Spatial Patterns of Hotels and Peer-To-Peer Accommodation in Barcelona.' Tourism Management 62: 278-291. https://doi.org/10. 1016/j.tourman.2017.05.003.

Hajibaba, Homa, and Dolnicar, Sara. 2018. 'Helping When Disaster Hits.' In Peer-to-Peer Accommodation Networks: Pushing the boundaries, edited by Sara Dolnicar, 237-245. Oxford: Goodfellow Publishers.

Hajibaba, Homa, and Sara Dolnicar. 2017. 'Substitutable by Peer-To-Peer Accommodation Networks.' Annals of Tourism Research 66 (C): 185-188. https://doi.org/10.1016/j.annals.2017.05.013.

Hall, C. Michael, Daniel Scott, and Stefan Gössling. 2020. 'Pandemics, Transformations and Tourism: Be Careful What You Wish for.' Tourism Geographies 22 (3): 577-598. https://doi.org/10.1080/14616688.2020.175 9131.

Hatzopoulos, Vassilis, and Sofia Roma. 2017. 'Caring for sharing? The collaborative economy under EU law.' Common Market Law Review 54 (1): 81-127.

Heo, Cindy Yoonjoung, Inès Blal, and Miju Choi. 2019. 'What is Happening in Paris? Airbnb, Hotels, and the Parisian Market: A Case Study.' Tourism Management 70: 78-88. https://doi.org/10.1016/j.tourman.2018.04.003.

HomeExchange. 'Home exchange: How does it work?' Accessed June 13, 2020. https://www.homeexchange.com/p/how-it-works-en.

Ioannides, Dimitri, Michael Röslmaier, and Egbert Van Der Zee. 2019. 'Airbnb as an Instigator of 'tourism bubble' Expansion in Utrecht's Lombok Neighbourhood.' Tourism Geographies 21 (5): 822-840. https://doi.org/10.1080/ 14616688.2018.1454505.

Karlsson, Logi, and Sara Dolnicar. 2016. 'Someone's Been Sleeping in My Bed.' Annals of Tourism Research 58: 159-162. https://doi.org/10.1016/j.annals. 2016.02.006.

Kim, Sodam, Kyung Young Lee, Chulmo Koo, and Sung-Byung Yang. 2018. 'Examining the Influencing Factors of Intention to Share Accommodations in Online Hospitality Exchange Networks.' Journal of Travel \& Tourism Marketing 35 (1): 16-31. https://doi.org/10.1080/10548408.2016. 1244024.

Koolhoven, R., E. D. C. Neppelenbroek, O. E. Santamaría Echeverria, and P. L. Verdi. 2016. Impulse Paper on Specific Liability Issues Raised by the Collaborative Economy in the Accommodation Sector. Groningen: University of Groningen Faculty of Law. 
Kumar, Vinnet, Avishek Lahiri, and Orhan Bahadir Dogan. 2018. 'A Strategic Framework for a Profitable Business Model in the Sharing Economy.' Industrial Marketing Management 69: 147-160. https://doi.org/10.1016/j.indmar man.2017.08.021.

Lee, Dayne. 2016. 'How Airbnb Short-Term Rentals Exacerbate Los Angeles's Affordable Housing Crisis: Analysis and Policy Recommendations.' Harvard Law \& Policy Review 10: 229-255.

Liang, Sai, Markus Schuckert, Rob Law, and Chih-Chien Chen. 2017. 'Be a 'Superhost': The Importance of Badge Systems for Peer-To-Peer Rental Accommodations.' Tourism Management 60: 454-465. https://doi.org/10. 1016/j.tourman.2017.01.007.

Lutz, Christoph, and Gemma Newlands. 2018. 'Consumer Segmentation within the Sharing Economy: The Case of Airbnb.' Journal of Business Research 88: 187-196. https://doi.org/10.1016/j.jbusres.2018.03.019.

Lyu, Jing, Mimi Li, and Rob Law. 2019. 'Experiencing P2P Accommodations: Anecdotes from Chinese Customers.' International Journal of Hospitality Management 77: 323-332. https://doi.org/10.1016/j.ijhm.2018.07.012.

Miguel, Cristina. 2017. Beyond engineered intimacy: Navigating social media platforms to manage intimate relationships. In Mediated Intimacies (pp. 130-142). Routledge.

Miguel, Cristina. 2018. Personal relationships and intimacy in the age of social media. London: Palgrave.

Moon, Hyoungeun, Li Miao, Lydia Hanks, and Nathaniel D. Line. 2019. 'Peer-To-Peer Interactions: Perspectives of Airbnb Guests and Hosts.' International Journal of Hospitality Management 77: 405-414. https://doi.org/10. 1016/j.ijhm.2018.08.004.

Paulauskaite, Dominyka, Raymond Powell, J. Andres Coca-Stefaniak, and Alastair M. Morrison. 2017. Living like a local: Authentic tourism experiences and the sharing economy. International Journal of Tourism Research, 19 6: 619-628.

Portolan, Ana. 2012. 'The Impact of Private Accommodation on Economic Development of Tourist Destination-the Case of Dubrovnik-Neretva County.' Oeconomica Jadertina 2 (1): 35-45.

PwC. 2016. 'Sharing or paring? Growth of the sharing economy.' Accessed October 25, 2020. https://www.pwc.com/hu/en/kiadvanyok/assets/pdf/sha ring-economy-en.pdf.

Ranchordas, Sofia, Gedeon, Zusanna, and Zurek, Karolina, 2016. Homesharing in the digital economy: The cases of Brussels, Stockholm, and Budapest. Brussels: European Commission. 
Richards, Greg. 2014. 'The New Geographies of Tourism: Space, Place and Locality.' Paper Presented at the Wageningen Geography Lectures, January 13, 2014.

Sans, Albert Arias, and Alan Quaglieri. 2016. 'Unravelling Airbnb: Urban Perspectives from Barcelona.' In Reinventing the Local in Tourism: Producing, Consuming and Negotiating Place, edited by Antonio Paolo Russo and Greg Richards, 209-228.

Schuckert, Markus, Mike Peters, and Gerhard Pilz. 2018. The co-creation of host-guest relationships via couchsurfing: A qualitative study. Tourism recreation research, 43 (2): 220-234.

Sdrali, Despina, Maria Goussia-Rizou, Panagiota Giannouli, and Michalis Kokkinis. 2015. 'Exploring Home Exchange in Greece: An Alternative Choice of Vacation.' Almatourism: Journal of Tourism, Culture and Territorial Development 6 (12): 211-214.

Shuqair, Saleh, Diego Costa Pinto, and Anna S. Mattila. 2019. 'Benefits of Authenticity: Post-failure Loyalty in the Sharing Economy.' Annals of Tourism Research 78: 102741. https://doi.org/10.1016/j.annals.2019. 06.008 .

Sigala, Marianna. 2017. 'Collaborative Commerce in Tourism: Implications for Research and Industry.' Current Issues in Tourism 20 (4): 346-355. https:// doi.org/10.1080/13683500.2014.982522.

Slee, Tom, 2015. What's yours is mine: Against the sharing economy. New York: O/R Books

Spitz, Tara. 2017. 'The Commodification of Hospitality: An Analysis of Tourism Encounters between Interculturality and Difference in Regard to Turkish Couchsurfing Experiences.' Master of Arts in Transcultural Communication, Turkey: Kadir Has University.

Stabrowski, F. (2017). "People as businesses': Airbnb and Urban Microentrepreneurialism in New York City.' Cambridge Journal of Regions, Economy and Society 10 (2), 327-347. https://doi.org/10.1093/cjres/rsx004. Stergiou, Dimitrios P., and Anna Farmaki. 2020. 'Resident Perceptions of the Impacts of P2P Accommodation: Implications for Neighbourhoods.' International Journal of Hospitality Management 91: 102411. https://doi.org/10. 1016/j.ijhm.2019.102411.

Sthapit, Erose, and Jano Jimenez-Barreto. 2018. "Exploring tourists' Memorable Hospitality Experiences: An Airbnb Perspective.' Tourism Management Perspectives 28: 83-92. https://doi.org/10.1016/j.tmp.2018.08.006. 
Stienmetz, J. L., Liu, A., and Tussyadiah, I. P. (2020). 'Impact of Perceived Peer To Peer Accommodation Development on Community Residents' WellBeing.' Current Issues in Tourism, 1-19. https://doi.org/10.1080/13683500. 2020.1797644.

Sung, Eunsuk, Hongbum Kim, and Daeho Lee. 2018. 'Why Do People Consume and Provide Sharing Economy Accommodation? A Sustainability Perspective.' Sustainability 10 (6): 2072. https://doi.org/10.3390/su1006 2072.

Sweeney, Majella, John Docherty-Hughes, and Paul Lynch. 2018. "Lifestyling entrepreneurs' Sociological Expressionism.' Annals of Tourism Research 69: 90-100. https://doi.org/10.1016/j.annals.2018.01.006.

Tran, Trang Ha, and Viachaslau Filimonau. 2020. 'The (de) Motivation Factors in Choosing Airbnb Amongst Vietnamese Consumers.' Journal of Hospitality and Tourism Management 42: 130-140. https://doi.org/10.1016/j. jhtm.2019.10.011.

Tussyadiah, Iis P., and Juho Pesonen. 2018. 'Drivers and Barriers of PeerTo-Peer Accommodation Stay-An Exploratory Study with American and Finnish Travellers.' Current Issues in Tourism 21 (6): 703-720. https://doi. org/10.1080/13683500.2016.1141180.

Williams, Lara. 2017. 'When Airbnb Rentals Turn into Nuisance Neighbours.' The Guardian. Accessed June 11, 2017. https://www.theguardian.com/tec hnology/2016/sep/17/airbnb-nuisance-neighbours-tribunal-ruling.

World Bank Group. 2018. 'Tourism and the Sharing Economy: Policy \& Potential of Sustainable P2P Accommodation.' Washington, DC: World Bank.

World Economic Forum. 2017. 'Collaboration in Cities: From Sharing to 'Sharing Economy.' World Economic Forum. Accessed December 2, 2017. http://www3.weforum.org/docs/White_Paper_Collaboration_in_Cities_rep ort_2017.pdf.

Zhang, Tingting, Diego Bufquin, and Can Lu. 2019. 'A Qualitative Investigation of Microentrepreneurship in the Sharing Economy.' International Journal of Hospitality Management 79: 148-157. https://doi.org/10.1016/j. ijhm.2019.01.010.

Zhu, Yunxia, Mingming Cheng, Jie Wang, Laikun Ma, and Ruochen Jiang. 2019. 'The Construction of Home Feeling by Airbnb Guests in the Sharing Economy: A Semantics Perspective.' Annals of Tourism Research 75: 308321. https://doi.org/10.1016/j.annals.2018.12.013. 


\section{Suggested Readings}

Hardy, Anne, Dolnicar, Sara and Vorobjovas-Pinta, Oscar. 2021. 'The Formation and Functioning of the Airbnb Neo-Tribe. Exploring Peer-ToPeer Accommodation Host Groups.' Tourism Management Perspectives 37: 100760 .

Liang, Sai, Xiaoxia Zhang, Chunxiao Li, Hui Li, and Xiaoyu Yu. 2021. 'Tit for Tat: Understanding the Responding Behavior of Property Hosts on Peer-To-Peer Rental Platforms.' International Journal of Contemporary Hospitality Management 33 (3): 1105-1126. https://doi.org/10.1108/IJCHM-072020-0705.

Reinhold, Stephan, and Dolnicar, Sara. 2021. 'Sharing Economy, Collaborative Consumption, Peer-To-Peer Accommodation or Trading of Space?' In Airbnb Before, During and After COVID-19, edited by Sara Dolnicar. University of Queensland. https://doi.org/10.6084/m9.figshare.14195945.

Zhu, Jingjie, Cheng, Mingming, and Li, Zhiyong. 2021. 'Peer-To-Peer Accommodation Experience and Guest Actual Recommendations: A Novel MixedMethod Approach.' Tourism Management Perspectives 38: 100816.

\section{Relevant Websites}

Are you part of the collaborative economy? https://ec.europa.eu/eurostat/web/ products-eurostat-news/-/ddn-20200205-1

European Holiday Home Association. https://ehha.eu.

Exploratory Study of consumer issues in peer-to-peer platform markets. https://ec.europa.eu/info/publications/exploratory-study-consumer-issuespeer-peer-platform-markets_en.

Short-term Accommodation Association UK. https://www.ukstaa.org/\#wel come. 
Open Access This chapter is licensed under the terms of the Creative Commons Attribution 4.0 International License (http://creativecommons.org/ licenses/by/4.0/), which permits use, sharing, adaptation, distribution and reproduction in any medium or format, as long as you give appropriate credit to the original author(s) and the source, provide a link to the Creative Commons license and indicate if changes were made.

The images or other third party material in this chapter are included in the chapter's Creative Commons license, unless indicated otherwise in a credit line to the material. If material is not included in the chapter's Creative Commons license and your intended use is not permitted by statutory regulation or exceeds the permitted use, you will need to obtain permission directly from the copyright holder.

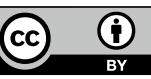

